\title{
UPAYA MENINGKATKAN HASIL BELAJAR IPA MENGGUNAKAN MODEL PICTURE AND PICTURE DENGAN MEDIA ANIMASI DI SDS MUHAMMADIYAH SELATTAHUN PELAJARAN 2016/2017
}

\author{
Oleh \\ Muhamad Faisal Budiono', Aidin Najihi \\ Email: Aidin Najihi@yahoo.com
}

\begin{abstract}
This study aims to improve learning outcomes and describe the learning activities of Va SDS Muhammadiyah Selat students using Animation media. The subjects in this study consisted of 27 students, 14 men and 13 women. Data collection techniques used were observation and tests. Data analysis uses qualitative and quantitative data analysis. The results of this study indicate that the use of animation media can improve the learning outcomes of science students in VA class SDS Muhammadiyah Straits of Kuala Kapuas. This is based on the results of research with the acquisition of values in the learning activities that have been carried out for two cycles, it can be concluded that: The use of poster media can improve student learning outcomes, this can be seen from the pre-action average $=40.55$ with classical completeness $7.40 \%$, the average cycle $\mathrm{I}=$ 45 with classical completeness $22.27 \%$ and cycle II $=72$ with classical completeness $88.88 \%$.
\end{abstract}

(C) Muhammadiyah University of Palangkaraya

Keywords: Science Learning Outcomes, and Picture and Picture Models, with Animation Media

\begin{abstract}
ABSTRAK
Penelitian ini bertujuan untuk meningkatkan hasil belajar dan mendeskripsikan aktivitas belajar peserta didik kelas $\mathrm{V}_{\mathrm{a}}$ SDS Muhammadiyah Selat dengan menggunakan media Animasi. Subjek dalam penelitian ini terdiri dari 27 orang peserta didik, 14 orang lakilaki dan 13 orang perempuan. Teknik pengumpulan data yang digunakan adalah observasi dan tes. Analisis data menggunakan analisis data kualitatif dan kuantitatif. Hasil penelitian ini menunjukan bahwa penggunaan media animasi dapat meningkatkan hasil belajar IPA peserta didik kelas $\mathrm{V}_{\mathrm{A}}$ SDS Muhammadiyah Selat Kuala Kapuas. Halini berdasarkan hasil penelitian dengan perolehan nilai dalam kegiatan pembelajaran yang telah dilakukan selama dua siklus, dapat disimpulkan bahwa : Penggunaan media poster dapat meningkatkan hasil belajar peserta didik, ini dapat dilihat dari rata-rata pra tindakan $=40,55$ dengan ketuntasan klasikal 7,40\%, rata-rata siklus $\mathrm{I}=45$ dengan ketuntasan klasikal 22,27\% dan siklus II $=72$ dengan ketuntasan klasikal 88,88 \%.
\end{abstract}

(C) Universitas Muhammadiyah Palangkaraya

Kata Kunci: Hasil Belajar IPA, dan Model Picture and Picture, dengan Media Animasi. 


\section{PENDAHULUAN}

Proses belajar mengajar
merupakan suatu proses yang
mengandung serangkaian perbuatan
guru dan peserta didik atas dasar
hubungan timbal balik yang
berlangsung dalam suasana edukatif untuk mencapai tujuan tertentu.

Dalam proses belajar mengajar guru dituntut untuk memiliki keterampilan dalam merancang strategi pembelajaran yang dapat mengarahkan peserta didik pada ketercapaian tujuan belajar yang dirumuskan.

Pembelajaran IPA ditujukan untuk membangun kompetensi antara lain kompetensi penguasaan konsep dan kompetensi metode ilmiah yang melibatkan keterampilan-keterampilan proses untuk memecahkan masalah dalam kehidupan sehari-hari. Untuk membangun kompetensi penguasaan konsep dan kompetensi metode ilmiah secara simultan maka pembelajaran IPA seyogyanya dilengkapi dengan media pembelajaran, bertujuan agar merangsang minat peserta didik dalam mengikuti pembelajaran, kemudian membawa suasana pembelajaran di kelas menjadi lebih aktif.

Ada beberapa jenis media pengajaran yang bisa digunakan dalam proses pengajaran. Pertama, media grafis seperti gambar, photo, grafik, bagan, atau diagram, poster, kartun, komik, dan lain - lain. Media grafis sering juga disebut media dua dimensi, yakni media yang mempunyai ukuran panjang dan lebar. Kedua, media tiga dimensi yaitu dalam bentuk model seperti model padat (solid model), model penampang, model susun, model kerja, mock up, diorama, dan lain - lain. Ketiga mediaproyeksi seperti slide, film strips, film, penggunaan OHP dan lain lain. Keempat penggunaan lingkungan sebagai media pengajaran.

Gerlach dan Ely (dalam Rodhatul jennah, 2009) mengatakan media apabila dipahami secara garis besar adalah manusia, materi, atau kejadian yang membangun kondisi yang membuat peserta didik mampu memperoleh pengetahuan, keterampilan dan sikap.Jadi, dapat disimpulkan bahwa media pembelajaran adalah segala sesuatu yang dapat dipergunakan untuk menyalurkan pesan atau informasi pembelajaran, sehingga merangsang pikiran, perasaan, perhatian dan minat serta perhatian pebelajar untuk belajar.

Menurut Salim (Zainul, Ahmad F dan Digginovac 2007;20), animasi adalah proses penciptaan efek gerak atau efek perubahan bentuk yang terjadi selama beberapa waktu (morphing).

\section{METODE PENELITIAN}

Penelitian ini merupakan penelitian tindakan kelas atau yang lebih akrab didengar yaitu PTK. Penelitian ini dilaksanakan di SDS Muhammadiyah Selat pada peserta didik kelas VA tahun pelajaran 2016/2017 pada semester genap bulan April sampai dengan Mei.

Subjek dalam penelitian ini adalah peserta didik kelas VA SDS Muhammadiyah Selat Kuala Kapuas yang terdiri dari 14 orang laki-laki dan 13 orang perempuan, sehingga 
keseluruhannya adalah 27 orang peserta didik.

Sumber data berasal dari siswa kelas $\mathrm{V}^{\mathrm{A}}$, guru mata pelajaran dan wali kelas. Proses pengumpulan data menggunakan teknik observasi dan teknik tes. Analisis data yang digunakan dalam penelitian ini analisis deskripsi kualitatif dan kuantitatif berdasarkan hasil observasi dan tes dari tiap-tiap siklus.

\section{HASIL DAN PEMBAHASAN}

Hasil observasi terhadap penerapan model pembelajaran kooperatif tipe TAI pada pembelajaran menyederhanakan pecahan kelas IV SDN 2 Selat Dalam adalah sebagai berikut:

Tabel 1.

Hasil Observasi Aktivitas Guru Siklus 1 dan 2

\begin{tabular}{|l|l|c|l|}
\cline { 2 - 4 } \multicolumn{1}{c|}{} & Skor & $\begin{array}{c}\text { Skor } \\
\text { rata- } \\
\text { rata }\end{array}$ & Kategori \\
\hline Siklus 1 & 46 & 2,87 & Cukup Baik \\
\hline Silkus 2 & 55,5 & 3,47 & Baik \\
\hline
\end{tabular}

Berdasarkan tabel 1 disimpulkan bahwa pada siklus 1 skor aktifitas guru mencapai 46 dengan skor rata-rata 2,87, sedangkan pada siklus 2 mencapai 55,5 dengan skor rata-rata 3,47. Skor dan rata-rata skor aktifitas guru termasuk dalam kategori Cukup baik.

\section{Tabel 2}

Hasil Observasi Aktivitas Peserta Didik Siklus 1 Dan 2

\begin{tabular}{|l|l|l|l|}
\multicolumn{1}{c|}{} & \multicolumn{1}{c|}{ Siklus 1 Dan 2 } \\
\cline { 2 - 4 } \multicolumn{1}{c|}{} & Skor & $\begin{array}{c}\text { Skor } \\
\text { rata-rata }\end{array}$ & Kategori \\
\hline Siklus 1 & 36 & 2,25 & Cukup Baik \\
\hline Silkus 2 & 54 & 3,40 & Baik \\
\hline
\end{tabular}

Berdasarkan tabel 2 disimpulkan bahwa pada siklus 1 skor aktifitas peserta didik mencapai 36 dengan skor rata-rata 2,25, sedangkan pada siklus 2 mencapai 54 dengan skor rata-rata 3,41. Skor dan rata-rata skor aktifitas guru termasuk dalam kategori baik.

\section{KESIMPULAN}

Aktivitas belajar peserta didik kelas $\mathrm{V}^{\mathrm{A}}$ pada mata pelajaran IPA dengan menggunakan media Animasi meningkat menjadi lebih aktif. Dapat dilihat dari nilai rata-rata aktivitas peserta didik pada siklus I yaitu 2,87 dan pada siklus II nilai rata-ratanya 3,47 .

Ada peningkatan hasil belajar peserta didik kelas $\mathrm{V}^{\mathrm{A}}$ pada mata pelajaran IPA dengan menggunakan media animasi. Hal ini dapat dilihat dari peningkatan rata-rata hasil belajar IPA pada pra tindakan yaitu rata-rata 40,55 dengan ketuntasan klasikal 7,40 \%, siklus I rata-rata 45 dengan ketuntasan klasikal 22,27 \%, dan siklus II yaitu rata-rata 72 dengan ketuntasan klasikal $88,88 \%$, maka pada siklus II penelitian tindakan dikatakan berhasil.

\section{DAFTAR PUSTAKA}

Jennah, Rodhatul. (2009). Media Pembelajaran. Banjarmasin: Antasari Press.

Zainul, Ahmad F and Diginnovac.2007. Membeuat Presentasi Multimedia Menggunakan Macromedia Flash Pro8.Elex Media Komputindo. Jakarta 